\title{
MENINGKATKAN SELF EFFICACY DENGAN PEMBELAJARAN PROBLEM POSING DI KELAS X SMK.
}

\section{IMPROVING SELF EFFICACY WITH PROBLEM POSING LEARNING IN CLASS X SMK}

\author{
Atrika Anggraeni, M. Pd ${ }^{*}$ \\ ${ }^{1}$ Pendidikan Guru Madrasah Ibtidiyah, STAI Miftahul Huda Al-Azhar Banjar, Jl. Pesantren No. \\ 02 Citangkolo Desa Kujangsari Kecamatan Langensari, 46324, Indonesia \\ ${ }^{*} E$-mail: atrikaanggi17@gmail.com \\ Hp: 082217606088
}

\begin{abstract}
ABSTRAK
Self efficacy merupakan keyakinan seseorang akan kemampuan yang dimiliki untuk mengerjakan latihan dan memperoleh hasil yang positif. Salah satu cara yang dapat digunakan meningkatkan kepercayaan diri siswa adalah dengan pembelajaran matematika menggunakan pendekatan problem posing yaitu menekankan pada belajar siswa untuk mempersiapkan diri dan menyelesaikan masalah mereka sendiri. Penelitian ini bertujuan untuk meningkatkan self efficacy siswa terhadap pembelajaran matematika pada kelas X Teknik Kendaraan Ringan dengan menggunakan pendekatan problem posing. Penelitian ini merupakan penelitian tindakan kelas dilaksanakan dalam dua siklus. Instrumen penelitian ini adalah penerapan pedoman observasi pembelajaran dengan menggunakan pendekatan problem posing. Teknik pengumpulan data dalam penelitian ini adalah lembar observasi, angket, dan tes. Selanjutnya, persentase hasil tes juga meningkat dari $68,75 \%$ pada periode pertama menjadi $78,13 \%$ pada periode kedua. Di sisi lain, pelaksanaan observasi pembelajaran dengan menggunakan pendekatan problem posing juga meningkat dan ini ditunjukkan oleh persentase rata-rata prestasi guru pada periode pertama adalah $89,2 \%$ dan prestasi siswa 85,8\%. Hasil ini mendapatkan peningkatan pada periode kedua untuk pencapaian guru dan siswa yaitu $94,4 \%$ dan $91,11 \%$. Akibatnya, self efficacy terhadap proses pembelajaran matematika di kelas $X$ Teknik kendaraan Ringan telah meningkat dengan menggunakan pendekatan problem posing.
\end{abstract}

Kata kunci: pendekatan pembelajaran, problem posing, self efficacy

\section{ABSTRACT}

Self efficacy is beliefs of a person will capability owned to do exercise and lead to results positive. One way that can be used increase confidence the students were to learning mathematics adopting the problem posing the emphasis on student learning to prepare and finish their own problems. Research is aimed to increase self efficacy students to learning mathematics on class $x$ technique light vehicle by adopting the problem posing .The research is research the act of class was done in two cycle. Research instruments this is the application of guidelines observation learning by adopting the problem posing. Technique data collection in this research was sheets of observation, chief, and tests. Furthermore, the percentage of test result is also improve from $68,75 \%$ in first period to $78,13 \%$ in second period. On the other hand, the implementation of learning observation by using problem posing approach has also improving and it is showed by the average percentage of teacher's achievement in first period is $89,2 \%$ and student's achievement $85,8 \%$. These results get increase in second period for both teacher and students' achievement which are $94,4 \%$ and $91,11 \%$. As a result, self efficacy toward 
Jurnal THEOREMS (The Original Research of Mathematics) Vol.5 No.1, Juli. hal.77-85

URL: http://jurnal.unma.ac.id/index.php/th

Naskah masuk: 2020-06-30 Naskah diperbaiki: 2020-07-10 Naskah diterima:2020-07-13

math learning process in grade $\mathrm{X}$ light vehicle engineering has been improving by using problem posing approach.

Keywords: learning approach, problem posing, self efficacy 


\section{PENDAHULUAN}

Sumber daya manusia merupakan salah satu aspek penting yang harus ditingkatkan guna menghadapi persaingan kualitas kehidupan. Matematika merupakan salah satu ilmu yang memegang peranan penting dalam kehidupan. Mata pelajaran matematika diberikan kepada semua siswa mulai Sekolah Dasar dengan tujuan untuk membekali siswa dengan kemampuan berpikir logis, analitis, sistematis, kritis, dan kreatif [1]. Untuk mengembangkan sikap dan kreativitas dalam pembelajaran matematika, guru perlu mengembangkan inovasi dalam pengajaran matematika. Guru harus mengembangkan berbagai jenis gaya pengajaran yang beragam, metode pengajaran, metode diskusi, metode berbasis masalah, interaksi kelas bervariasi, dan menggunakan pendekatan realistis atau kontekstual [2]. Guru perlu memperhatikan karakteristik dengan mengenali perbedaan setiap siswanya dengan mengetahui faktor-faktor yang terkait dengan proses pembelajaran siswa. Adapun beberapa faktor psikologis dalam diri siswa antara lain: self efficacy, motivasi, emosi, dan lain sebagainya. Dalam proses belajar ada salah satu faktor yang mempengaruhinya salah satunya yaitu self efficacy siswa.

Self efficacy didefinisikan sebagai pertimbangan seseorang tentang kemampuan dirinya untuk dicapai tingkatan kinerja yang diinginkan atau ditentukan, yang akan mempengaruhi tindakan selanjutnya dimana ia berusaha meneliti tingkat, keumuman, dan kekuatan diri seluruh kegiatan dan konteks [3]. Pertimbangan self efficacy akan lebih berorientasi kepada tugastugas dan situasi yang spesifik, akan lebih konstektual, dan individu membuat keputusan-keputusan dengan didasarkan pada sejumlah tujuan (goal). Seseorang yang memiliki self efficacy akan berusaha dan yakin agar mereka bisa berhasil dalam mencapai tujuan, mereka harus berupaya secara intensif dan bertahan ketika mereka menghadapi kesulitan. Semakin besar self efficacy seseorang, makin besar upaya, ketekunan, dan fleksibilitasnya.

Self efficacy terhadap matematika telah menjadi faktor yang diketahui mempengaruhi prestasi siswa dalam matematika [4]. Cooney \& Cotton dalam Khiat juga menemukan beberapa siswa memandang matematika sebagai hal yang menarik, sementara yang lain menganggap matematika sebagai hal yang membosankan [5]. Meskipun demikian, setiap orang harus belajar matematika karena itu adalah sarana untuk menyelesaikan masalah dalam kehidupan sehari-hari

Berdasarkan observasi dan wawancara dengan guru mata pelajaran yang telah dilakukan oleh peneliti di kelas $X$ TKR. Hasil wawancara tersebut menunjukkan bahwa secara umum self efficacy siswa kelas X TKR masih belum optimal dalam mengikuti pelajaran matematika. Beberapa siswa terlihat kurang antusias dalam kegiatan pembelajaran seperti lebih banyak mendengarkan dari pada mengutarakan pendapat. Hal ini disebabkan antara lain pembelajaran masih monoton, kurang bervariasi dan umumnya masih berpusat pada guru. Tidak banyak melibatkan siswa secara maksimal dalam proses pembelajaran. Keyakinan siswa dalam memecahkan suatu soal matematika masih relative kurang, dan ini disebabkan oleh banyak siswa yang kurang peduli dan acuh tak acuh ketika pembelajaran berlangsung. Hal ini dimungkinkan matematika tumbuh melalui penyampaian yang bervariasi, menyenangkan, mudah dipahami, dan 
menunjukkan kegunaan matematika dalam kehidupan. Salah satu variasi pembelajaran yang dapat diterapkan adalah pendekatan problem posing.

Belajar matematika menggunakan pendekatan problem posing yang menekankan pada belajar siswa untuk mempersiapkan diri dan menyelesaikan masalah mereka sendiri. Kegiatan pembangunan masalah ini memberikan kesempatan seluasluasnya bagi siswa untuk membangun pengetahuan sesuai dengan perkembangan kemampuan berpikir [6]. Informasi yang diproses dalam pikiran dan setelah dipahami siswa akan dapat membuat pertanyaan, sehingga menyebabkan pembentukan pemahaman yang lebih solid pada siswa. Kegiatan itu akan membuat siswa secara aktif membangun hasil belajar

Dalam pembelajaran matematika dengan pendekatan problem posing, siswa diharapkan membuat sendiri atau mengajukan pertanyaan sesuai dengan masalah yang dihadapi seharihari berkenaan dengan materi yang dipelajari harus diselesaikan sendiri oleh siswa tanpa harus dijawab langsung oleh guru. Salah satu pendekatan pembelajaran yang dapat memotivasi siswa untuk berpikir kritis, kreatif dan interaktif adalah problem posing atau pengarsipan masalah yang diuraikan dalam bentuk pertanyaan [7], sehingga siswa diberi kesempatan untuk mengekspresikan ide-ide yang dimiliki baik secara individu maupun kelompok. Hal itu dapat membuat sikap pada siswa menjadi lebih baik terhadap pembelajaran yang diajarkan.

Hubungan problem posing dengan self efficacy salah satunya menurut hasil penelitian Tatiriah, Edi \& Kadir menunjukkan bahwa terdapat perbedaan self efficacy yang signifikan antara kelompok siswa yang mengikuti pembelajaran berbasis masalah dan pembelajaran langsung

\section{METODE PENELITIAN}

Jenis penelitian ini adalah classroom action research atau penelitian tindakan kelas (PTK) yang dilakukan dengan cara berkolaborasi dengan guru matematika di kelas X TKR. Penelitian tindakan ini menggunakan desain yang dikembangka oleh Kemmis \& Mc Taggart yang terdiri dari empat tahap berulang, yaitu planning (perencanaan), action (pelaksanaan), observation (pengamatan), dan reflection (refleksi) [9]. Penenlitian ini dengan jumlah responden 32 siswa dilaksanakan dalam dua siklus, siklus pertama adalah 3 kali pertemuan, dan siklus kedua sekitar 3 kali pertemuan. Instrumen penelitian ini adalah penerapan pedoman observasi pembelajaran dengan menggunakan pendekatan problem posing. Lembar observasi digunakan untuk mengetahui keterlaksanaan pembelajaran, angket digunakan untuk mengetahui self efficacy siswa, sedangkan tes digunakan untuk mengukur ketercapaian kompetensi dasar siswa. Gambar berikut adalah bagan aktivitas CAR model Kemmis\& McTaggart [10]

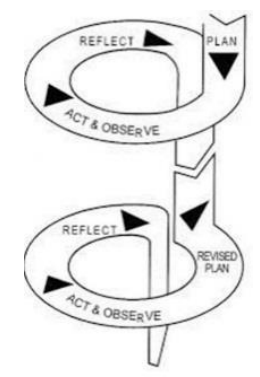

\section{Gambar 1. Alur Penelitian}

\section{HASIL DAN PEMBAHASAN}

Sebelum penelitian tindakan dilakukan, terlebih dahulu dilakukan observasi awal yang bertujuan untuk mengetahui kondisi awal siswa dan kegiatan pembelajaran matematika di kelas $X$ TKR. Secara umum, pelaksanaan pembelajaran 
matematika di kelas masih menggunakan pendekatan ekspositori dan jarang menggunakan masalahmasalah yang berkaitan dengan matematika. Selanjutnya, untuk kondisi awal self efficacy, pengetahuan, dan keterampilan siswa dalam matematika dilihat pada Tabel 1.

Tabel 1.

Kondisi Awal Siswa Kelas X TKR

\begin{tabular}{|c|c|c|}
\hline Variabel & Kriteria & $\begin{array}{c}\text { Kondisi } \\
\text { Awal }\end{array}$ \\
\hline \multirow{4}{*}{ Self Efficacy } & Sangat Tinggi & $0 \%$ \\
\cline { 2 - 3 } & Tinggi & $6.25 \%$ \\
\cline { 2 - 3 } & Sedang & $53.13 \%$ \\
\cline { 2 - 3 } & Rendah & $40.63 \%$ \\
\cline { 2 - 3 } & Sangat Rendah & $0 \%$ \\
\hline $\begin{array}{c}\text { Pengetahua } \\
\text { n/Keteram } \\
\text { pilan }\end{array}$ & \multicolumn{2}{|c|}{ Siswa yang tuntas $=$} \\
\hline \multicolumn{2}{|c|}{$67.187 \%$} \\
\hline
\end{tabular}

\section{A. Deskripsi Pelasanaan Tindakan Siklus I}

1) Planning

Pada tahap perencanaan ini, dilakukan persiapan antara lain menentukan materi pembelajaran, menyusun rencana pelaksanaan pembelajaran (RPP), menyusun lembar kerja siswa (LKS), menyusun instrumen penilaian, dan menyusun lembar observasi keterlaksanaan pembelajaran. Materi pembelajaran yang digunakan pada siklus I adalah bilangan berpangkat, bentuk akar dan logaritma.

Pembelajaran yang direncanakan dalam RPP merupakan pembelajaran dengan pendekatan problem posing yang berjumlah 3 kali pertemuan. Pada setiap pertemuan, siswa akan diberikan LKS yang disusun dengan pendekatan problem posing dan memuat tahapan-tahapan problem posing, yaitu orientasi pada masalah, mengorganisasikan siswa untuk belajar, membimbing penyelidikan individual mapun kelompok, mengembangkan dan menyajikan hasil karya, serta menganalisis dan mengevaluasi proses pemecahan masalah. Selain itu, pada setiap pertemuan pun akan dilakukan penilaian dengan menggunakan lembar observasi yang disusun untuk mengetahui keterlaksanaan pembelajaran. Selanjutnya, setelah 3 kali pertemuan, akan dilaksanakan penilaian self efficacy, pengetahuan, dan keterampilan siswa dalam matematika. Instrumen yang disusun untuk penilaian tersebut yaitu angket dan tes tertulis.

2) Action

Pelaksanaan siklus I dilakukan dalam tiga pertemuan dengan durasi waktu 6 jam pelajaran atau 240 menit. Pelaksanaan pembelajaran dilakukan oleh guru dan disesuaikan dengan RPP, sedangkan peneliti melakukan observasi. Selanjutnya, agar pembelajaran lebih efektif, kegiatan pembelajaran dilakukan dengan cara diskusi secara berkelompok.

Pertemuan pertama dilaksanakan pada hari Kamis, 8 Agustus 2019 pukul 07.15 WIB - 08.35 WIB. Materi pembelajaran pada pertemuan pertama adalah mengoperasikan dan menentukan nilai bilangan berpangkat dengan menggunakan sifat-sifatnya. Kegiatan pembelajaran dibuka dengan salam dan berdoa, lalu dilanjutkan dengan kegiatan-kegiatan pendahuluan seperti pemberian motivasi dan apersepsi. Pada tahap inti, guru mengelompokkan empat sampai lima siswa ke dalam satu kelompok. Selanjutnya, setiap kelompok melakukan diskusi untuk menyelesaikan masalah-masalah yang disajikan pada LKS. Setelah itu, beberapa kelompok siswa ditunjuk untuk mempresentasikan hasil diskusi kelompoknya di depan kelas 
dan jika hasil diskusi mengalami kekeliruan, guru bertugas untuk memperbaikinya. Sebelum kegiatan pembelajaran diakhiri dengan doa, guru dan siswa terlebih dahulu melakukan refleksi kegiatan pembelajaran.

Pertemuan kedua dilaksanakan pada hari Senin, 12 Agustus 2019 pukul 07.40 WIB - 09.00 WIB. Materi pembelajaran pada pertemuan kedua adalah mengoperasikan dan menentukan nilai bentuk akar dengan menggunakan sifat-sifatnya. Secara keseluruhan, kegiatan pembelajaran pada pertemuan kedua serupa dengan kegiatan pada pertemuan pertama.

Pertemuan ketiga dilaksanakan pada hari Kamis, 15 agustus 2019 pukul 07.15 WIB - 08.35 WIB. Materi pembelajaran pada pertemuan ketiga adalah mengoperasikan dan menentukan nilai logaritma dengan menggunakan sifat-sifatnya. Secara keseluruhan, kegiatan pembelajaran pada pertemuan ketiga tidak berbeda jauh dengan kegiatan pembelajaran pada pertemuan pertama dan pertemuan kedua. Selain itu, pada pertemuan ini, guru juga menginformasikan kepada siswa bahwa pada hari Senin, 26 Agustus 2019 akan dilaksanakan tes mengenai materi bilangan berpangkat 3) Observation

Pengamatan yang dilakukan berupa pengamatan terhadap keterlaksanaan pembelajaran, hasil angket self efficacy, dan hasil tes siswa. Adapun hasil pengamatan terhadap keterlaksanaan disajikan pada Tabel 2.

Tabel 2.

\section{Hasil Observasi Keterlaksanaan}

Pembelajaran selama siklus I

\begin{tabular}{|c|c|c|}
\hline $\begin{array}{c}\text { Perte } \\
\text { muan }\end{array}$ & $\begin{array}{c}\text { Keterlaksanaa } \\
\text { n Aktivitas } \\
\text { Guru (\%) }\end{array}$ & $\begin{array}{c}\text { Keterlaksana } \\
\text { an Aktivitas } \\
\text { Siswa (\%) }\end{array}$ \\
\hline 1 & 84 & 73.3 \\
\hline
\end{tabular}

\begin{tabular}{|c|c|c|}
\hline 2 & 90 & 90 \\
\hline 3 & 90 & 90 \\
\hline Mean & $\mathbf{8 9 . 1 6}$ & $\mathbf{8 5 . 8 3}$ \\
\hline \multicolumn{2}{|c|}{ Dari tabel diatas dihasilkan }
\end{tabular}

keterlaksanaan guru pada siklus pertama dengan rata-rata 89.16 sedangkan keterlaksanaan siswa pada siklus pertama dengan rata-rata 85.83. Selanjutnya, hasil angket self efficacy dapat dilihat pada Tabel 3.

Tabel 3.

Hasil Angket Self Efficacy

\begin{tabular}{|c|c|}
\hline Kriteria & $\begin{array}{c}\text { Persentase } \\
\text { Siswa }\end{array}$ \\
\hline Sangat Tinggi & $21.875 \%$ \\
\hline Tinggi & $37.50 \%$ \\
\hline Sedang & $37.50 \%$ \\
\hline Rendah & $6.25 \%$ \\
\hline Sangat Rendah & $0 \%$ \\
\hline
\end{tabular}

Dari tabel diatas dihasilkan hasil angket self efficacy pada siklus pertama memiliki npresentase siswa tertinggi yaitu pada kriteria tinggi dan sedang yaitu $37.50 \%$. Setelah dilakukan analisis terhadap tes yang dilakukan siswa, diperoleh nilai ratarata dari keseluruhan siswa adalah 74 dan persentase ketuntasan klasikal $68.75 \%$.

4) Reflection

Berdasarkan hasil observasi, terlihat bahwa hasil penelitian pada siklus I yang telah mencapai indikator keberhasilan yang ditetapkan yaitu keterlaksanaan aktivitas guru, self efficacy, pengetahuan, dan keterampilan dalam matematika. Sedangkan untuk keterlaksanaan aktivitas siswa belum mencapai indikator keberhasilan. Hal ini dikarenakan adanya kendala-kendala dalam pembelajaran, seperti kurang aktifnya siswa dalam kegiatan pembelajaran, ketidakhadiran siswa, keterbatasan waktu dan kesulitan siswa dalam memecahkan masalah.

Untuk meminimalisasi kendalakendala tersebut terjadi pada siklus II, 
maka direncanakan perbaikan seperti pengajuan pertanyaan-pertanyaan kepada siswa yang kurang aktif, pemberian bimbingan dan pengarahan yang lebih baik.

\section{B. Deskripsi Pelasanaan Tindakan Siklus II}

1) Planning

Tahap perencanaan pada siklus II tidak berbeda dengan tahap perencanaan pada siklus I. Hanya saja, perencanaan dilakukan dengan memperhatikan refleksi pada siklus I. Hal-hal yang dilakukan pada tahap ini yaitu menentukan materi pembelajaran, menyusun RPP, menyusun LKS, menyusun instrumen penilaian, dan menyusun lembar observasi keterlaksanaan pembelajaran. Materi pembelajaran yang digunakan pada siklus II adalah bilangan berpangkat, bentuk akar dan logaritma

2) Action

Pelaksanaan siklus II dilakukan dalam tiga pertemuan dengan durasi waktu 6 jam pelajaran atau 240 menit. Pelaksanaan pembelajaran dilakukan oleh guru dan disesuaikan dengan RPP, sedangkan peneliti melakukan observasi. Selanjutnya, agar pembelajaran lebih efektif, kegiatan pembelajaran dilakukan dengan cara diskusi secara berkelompok.

Pertemuan pertama dilaksanakan pada hari Senin, 2 September 2019 pukul 07.40 WIB - 09.00 WIB. Materi pembelajaran pada pertemuan pertama adalah memecahkan masalah kontekstual yang berkaitan dengan operasi pada bilangan berpangkat. Kegiatan pembelajaran dibuka dengan salam dan berdoa, lalu dilanjutkan dengan kegiatan-kegiatan pendahuluan seperti pemberian motivasi dan apersepsi. Pada tahap inti, guru mengelompokkan siswa menjadi beberapa kelompok yang beranggotakan empat sampai lima orang siswa. Selanjutnya, setiap kelompok melakukan diskusi untuk menyelesaikan masalah-masalah yang disajikan pada LKS. Setelah itu, beberapa kelompok siswa ditunjuk untuk mempresentasikan hasil diskusi kelompoknya di depan kelas dan jika hasil diskusi mengalami kekeliruan, guru bertugas untuk memperbaikinya. Sebelum kegiatan pembelajaran diakhiri dengan doa, guru dan siswa terlebih dahulu melakukan refleksi kegiatan pembelajaran.

Pertemuan kedua dilaksanakan pada hari Kamis, 5 September 2019 pukul 07.15 WIB - 08.35 WIB. Materi pembelajaran pada pertemuan kedua adalah memecahkan masalah kontekstual yang berkaitan dengan operasi pada bentuk akar, Secara keseluruhan, kegiatan pembelajaran pada pertemuan kedua serupa dengan kegiatan pada pertemuan pertama.

Pertemuan ketiga dilaksanakan pada hari Senin, 9 September 2019 pukul 07.15 WIB - 08.35 WIB. Materi pembelajaran pada pertemuan ketiga adalah memecahkan masalah kontekstual yang berkaitan dengan operasi pada logaritma, kegiatan pembelajaran pada pertemuan ketiga tidak berbeda jauh dengan kegiatan pembelajaran pada pertemuan pertama dan pertemuan kedua. Selain itu, pada pertemuan ini, guru juga menginformasikan kepada siswa bahwa pada hari Kamis, 12 September 2019 akan dilaksanakan tes mengenai materi bilangan berpangkat, bentuk akar, dan logaritma

3) Observation

Pengamatan yang dilakukan berupa pengamatan terhadap keterlaksanaan pembelajaran, hasil angket self efficacy, dan hasil tes siswa. Adapun hasil pengamatan terhadap 
keterlaksanaan pembelajaran disajikan pada Tabel 4.

Tabel 4.

Hasil Observasi Keterlaksanaan

Pembelajaran selama siklus II

\begin{tabular}{|c|c|c|}
\hline $\begin{array}{c}\text { Perte } \\
\text { muan }\end{array}$ & $\begin{array}{c}\text { Keterlaksana } \\
\text { an Aktivitas } \\
\text { Guru (\%) }\end{array}$ & $\begin{array}{c}\text { Keterlaksanaa } \\
\text { n Aktivitas } \\
\text { Siswa (\%) }\end{array}$ \\
\hline 1 & 93.3 & 86.7 \\
\hline 2 & 93.3 & 90 \\
\hline 3 & 96.7 & 96.7 \\
\hline Mean & $\mathbf{9 0 , 6 7}$ & $\mathbf{8 6 , 6 7}$ \\
\hline \multicolumn{2}{|c|}{ Dari tabel diatas dihasilkan } \\
\hline
\end{tabular}

keterlaksanaan guru pada siklus kedua dengan rata-rata 90.67 sedangkan keterlaksanaan siswa pada siklus kedua dengan rata-rata 86.67. Selanjutnya, hasil angket self efficacy dapat dilihat pada Tabel 5 .

Tabel 5.

Hasil Angket Self Efficacy

\begin{tabular}{|c|c|}
\hline Kriteria & $\begin{array}{c}\text { Persentase } \\
\text { Siswa }\end{array}$ \\
\hline Sangat Tinggi & $31.25 \%$ \\
\hline Tinggi & $53.13 \%$ \\
\hline Sedang & $15.63 \%$ \\
\hline Rendah & $0 \%$ \\
\hline Sangat Rendah & $0 \%$ \\
\hline
\end{tabular}

Dari tabel diatas dihasilkan hasil angket self efficacy pada siklus kedua memiliki npresentase siswa tertinggi yaitu pada kriteria tinggi yaitu $53.13 \%$. Setelah dilakukan analisis terhadap tes yang dilakukan siswa, diperoleh nilai rata-rata dari keseluruhan siswa adalah 76 dan persentase ketuntasan klasikal 78.13\%. 4) Reflection

Berdasarkan hasil observasi, terlihat bahwa keterlaksanaan pembelajaran, baik guru maupun siswa, pada siklus II telah mencapai indikator keberhasilan yang ditetapkan. Hal ini dapat tercapai dikarenakan kendala-kendala pada siklus I dapat diatasi sehingga terjadi perbaikan dalam proses pembelajaran. Namun meskipun demikian, masih terjadi beberapa kendala, seperti masih ada beberapa siswa yang kurang aktif dan kesulitan pada saat kegiatan pembelajaran, serta adanya siswa yang tidak hadir. Selain keterlaksanaan pembelajaran, self efficacy siswa dalam matematika serta pengetahuan dan keterampilan siswa pada siklus II mengalami kenaikan pencapaian indikator keberhasilan yang ditetapkan.

Hal itu sangat lazim terjadi dalam matematika secara utuh, sebab konsep matematika bersifat hirarkis dan saling terkait. Hal ini juga dikemukakan bahwa untuk mempelajari matematika haruslah secara kontinyu dan tidak terputusputus, belajar matematika dengan terputus-putus akan mengganggu terjadinya proses belajar mengajar [11]. Dengan demikian dapat dikatakan bahwa penerapan pendekatan problem posing memenuhi prinsip kekontinuan konsep matematika. Hasil yang diperoleh pada siklus II menunjukkan bahwa pelaksanaan pembelajaran dengan pendekatan problem posibng mampu meningkatkan self efficacy siswa dalam matematika setelah dilakukan beberapa perbaikan dari siklus I ke siklus II. Sehingga dapat disimpulkan bahwa tindakan perbaikan dalam penelitian ini cukup dan dapat dihentikan.

\section{KESIMPULAN}

Berdasarkan hasil penelitian dan pembahasan, diperoleh simpulan bahwa pembelajaran matematika dengan pendekatan problem posing pada siswa kelas $X$ Teknik Kendaraan Ringan SMK Tunas bangsa Tahun Ajaran 2019/2020 dapat memperbaiki proses pembelajaran dan meningkatkan self efficacy siswa dalam matematika setelah dilakukan selama dua siklus. 


\section{SARAN}

Saran yang diajukan dalam penelitian ini adalah pendekatan problem posing dapat dijadikan alternatif pembelajaran matematika untuk meningkatkan sikap siswa terhadap pembelajaran matematika dan meningkatkan kualitas pembelajaran.

\section{UCAPAN TERIMA KASIH}

Terima kasih kepada pihak-pihak yang telah membantu penelitian ini, serta rekan-rekan yang telah memberikan saran serta kritik yang membantu penelitian ini.

\section{DAFTAR PUSTAKA}

[1] Depdiknas, Peraturan Menteri Pendidikan dan Kebudayaan Republik Indonesia Nomor 81A tahun (2013). Tentang Implementasi Kurikulum Pedoman Umum Pembelajaran. Jakarta

[2] Marsigit, "Developing the Attitude and Creativity in Mathematics Eduaction,". (2011) in The International and The Fourth National Conference on Mathematics (UNY, Yogyakarta

[3] A. Bandura. (1997). Self-Efficacy The Exercise of Control. New York: W.H. Freeman and Company

[4] L. Mohamed \& H. Waheed, Secondary Students'attitude Towards Mathematics in a Selected School of Maldives. (2011). International Journal of Humanities and Social Science, Vol.1, pp. 277-281

[5] Khiat, A Grounded Theory Approach: Conceptions of Understanding in Engineering Mathematics Learning. (2010). The Quantum report, Vol. 15, pp. 14591488

[6] Yaya S. Kusumah, "Model-Model Pembelajaran Matematika untuk
Meningkatkan Kognitif dan Afektif Siswa Sekolah Menengah". (2004). in National Seminar of Mathematics Education (Department of Mathematics Education, UNY, 2004), pp. 8

[7] Suryosubroto. (2009). Proses Belajar Mengajar di Sekolah. Jakarta: PT Rineka Cipta

[8] Tatiriah, Edi Cahyono \& Kadir. (2014). Peningkatan Kemampuan Penalaran Matematik dan self efficacy siswa SMA melalui penerapan pendekatan problem posing. (Department of Mathematics Education, UNY)

[9] A. Suharsimi. (2013). Penelitian Tindakan Kelas. Jakarta: PT Bumi Aksara

[10] D. Hopkins. (2008). A Teacher's Guide to Classroom Research Ed. 4 (McGraw Hill-Open. New York: University Press,

[11] Herma, H. (1990). Strategi Belajar Mengajar Matematika. Malang: IKIP Malang. 